\title{
Aplikasi Formulasi Cair Trichoderma harzianum dan Trichoderma virens sebagai Agen Pengendali Hayati (APH) Penyakit Hawar Daun (Phytopthora palmivora) pada Bibit Kakao Application Liquid Formulation Trichoderma harzianum and Trichoderma virens as Biological Control Agent (APH) Leaf Blight (Phytopthora palmivora) on Cocoa Seedlings
}

\author{
Desi Arida ${ }^{1}$, Rina Sriwati ${ }^{2}$, Tjut Chamzurni ${ }^{2 *}$ \\ ${ }^{1}$ Jurusan Agroteknologi, Fakultas Pertanian, Universitas Syiah Kuala \\ ${ }^{2}$ Jurusan Proteksi Tanaman, Fakultas Pertanian, Universitas Syiah Kuala \\ Tgk Hasan Krueng Kalee No. 3, Banda Aceh, 23111 \\ Corresponding author: desiarida50@gmail.com
}

\begin{abstract}
Abstrak. Pencegahan penyakit hawar daun oleh jamur Phytophthora palmivora pada kakao (Theobroma cacao L.) menggunakan fungisida dapat berdampak buruk terhadap lingkungan dan menimbulkan resistensi, sehingga untuk mengatasinya diperlukan alternatif lain dengan menggunakan Agen Antagonis Hayati (APH) seperti cendawan Trichoderma spp. Perbanyakan cendawan Trichoderma spp. dapat diperbanyak dengan berbagai media, salah satunya dengan formulasi cair. Penelitian ini bertujuan untuk mengetahui pengaruh kombinasi dari T. harzianum dan T.virens dalam mengendalikan penyakit hawar daun P. palmivora pada bibit kakao. Penelitian ini dilaksanakan di Laboratorium Penyakit Tumbuhan dan Kebun Percobaan Fakultas Pertanian Universitas Syiah Kuala pada bulan Januari 2018 sampai dengan Juli 2018. Penelitian ini menggunakan Rancangan Acak Lengkap non faktorial yang terdiri dari 4 perlakuan dengan 5 ulangan, Apabila uji F menunjukkan pengaruh nyata, dilanjutkan dengan uji beda nyata terkecil pada taraf 5\%. Peubah yang diamati yaitu masa inkubasi, kejadian penyakit, keparahan penyakit jumlah daun, lebar daun, diameter batang dan tinggi tanaman. Hasil penelitian ini menunjukkan aplikasi formulasi cair $T$. harzianum dan $T$. virens berpengaruh terhadap peubah masa inkubasi, kejadian penyakit, keparahan penyakit dan tinggi tanaman yaitu $18,75 \mathrm{~cm}$ per tanaman.
\end{abstract}

Kata kunci : Kakao, T. harzianum, T.virens, Phytophthora palmivora, Formulasi cair

Abstract. Prevention of leaf blight by the fungus Phytophthora palmivora on cocoa (Theobroma cacao L.) using fungicides may adversely affect the environment and cause resistance, so to resolve it needed another alternative by using Biological Antagonist Agent (APH) such as Trichoderma spp. The multiplication of Trichoderma spp. can be reproduced with various media, one of them with a liquid formulation. This study aimed to determine the effect of the combination of $T$. harzianum and T.virens in controlling P. palmivora leaf blight in cocoa seedlings. This research was conducted at the Laboratory of Plant Disease and Experimental Garden of the Faculty of Agriculture, Syiah Kuala University in January 2018 until July 2018. This study used a non-factorial Completely Randomized Design consisting of 4 treatments with 5 replications. If the $\mathrm{F}$ test shows a real effect, it will continue by the smallest real difference test at the level of 5\%. The variables observed were incubation period, disease incidence, disease severity, number of leaves, leaf width, stem diameter and plant height. The results of this study showed that the application of liquid formulation T. harzianum and T. virens had an effect on the incubation period, disease incidence, disease severity and plant height of $18.75 \mathrm{~cm}$ per plant.

Keywords: Cocoa, T. harzianum, T.virens, Phytophthora palmivora, Liquid Formulations. 


\section{PENDAHULUAN}

Kakao (Theobroma cacao L.) merupakan salah satu komoditas unggulan subsektor perkebunan di Indonesia berperan sebagai sumber devisa negara, penyerap lapangan kerja,dan pendapatan petani yang memberikan kontribusi yang sangat penting dalam struktur perekonomian Indonesia (Afriyeni et al., 2013; Dinas Perkebunan dan Hortikultura, 2016). Di Aceh, khususnya di kabupaten Pidie, luas lahan perkebunan kakao pada tahun 2012 dengan hasil produktivitas mencapai 4.499 ton dan mengalami penurunan yang signifikan menjadi 2.674 ton pada tahun 2013(Badan Pusat Statistik Provinsi Aceh, 2013). Budidaya kakao menghadapi banyak kendala, antara lain serangan cendawan Phytophthora palmivora yang menyerang semua organ tanaman pada semua tingkatan umur tanaman kakao. Serangan $P$. palmivora telah meluas sehingga keragaman patogeniknya menjadi ancaman terhadap penurunan produksi tanaman kakao (Umrah et al., 2009).

Salah satu upaya dalam peningkatan produktivitas dan kualitas tanaman kakao adalah menggunakan agen pengendali hayati (APH) yang bersifat ramah lingkungan yaitu cendawan Trichoderma spp. Trichoderma merupakan salah satu cendawan APH yang hidup bebas di alam dan sangat banyak terdapat di akar, tanah, dan daun serta memiliki kemampuan memparasit fungi lain. Cendawan Trichoderma menghasilkan metabolit sekunder (viridin dan trikomidin, bersifat antibiotik) yang dapat diperoleh dari berbagai formulasi diantaranya formulasi cair (Soesanto, 2014). Formulasi cair adalah bentuk produk biofungisida yang diaplikasikan pada daun dan batang (Suwahyono, 2013). T. virens memiliki kemampuan antibiotis dan mikroparasit dalam menghambat perkembangan $P$. palmivora (Sriwati, 2012). T. Harzianum dapat menghasilkan enzim hidrolitik $\beta$ 1,3 glukanase, selulase, lipoprotase, dan kitinase yang mampu melakukan penetrasi kedalam hifa cendawan lain (Suwahyono, 2013). Berdasarkan uraian diatas maka perlu dilakukan penelitian dengan menggunakan formulasi cair $T$. harzianum dan $T$. virens terhadap penyakit hawar daun ( $P$. palmivora) pada bibit kakao (Theobroma cacao L.).

\section{METODE PENELITIAN}

Penelitian ini dilaksanakan di Laboratorium Penyakit Tumbuhan dan Kebun Percobaan Fakultas Pertanian Universitas Syiah Kuala pada bulan Januari sampai dengan Juli 2018. Alat yang digunakan adalah cawan petri, gelas ukur, tabung reaksi, rak tabung reaksi, haemocytometer, Multi Shaker MMS, laminar air flow, mikroskop, tabung erlenmeyer, autoclaf, ruang incubator, jarum ose, lampu bunsen, scapel, kompor gas, timbangan digital, jerigen ukuran 5 Liter, meteran, corong, pipet tetes, gunting, saringan, ember, ayakan tanah, kamera dan tudors prayer. Bahan yang digunakan adalah buah kakao sehat varietas lindak, kulit buah kakao yang terinfeksi Phytophthora palmivora, isolat biakan murni T. harzianum dan T. virens (koleksi Laboratorium Penyakit Tumbuhan Program Studi Proteksi Tanaman Fakultas Pertanian Universitas Syiah Kuala), aquades, media Potato Dextrose Agar (PDA), tanah, pupuk kandang, sekam, alkohol 70\%, aluminium foil, air cucian beras, air kelapa tua, gula pasir, plastik wrap, polybag, kertas label, tissue, kapas, kertas saring biasa, abu gosok dan alat tulis. Rancangan yang digunakan

Aplikasi Formulasi Cair Trichoderma harzianum dan Trichoderma virens sebagai Agen Pengendali Hayati (APH) Penyakit Hawar Daun (Phytopthora palmivora) pada Bibit Kakao 
adalah Rancangan Acak Lengkap (RAL) nonfaktorial yang terdiri dari 4 perlakuan dengan 5 ulangan.

\section{Pelaksanaan Penelitian}

\section{Persiapan media Potato Dectrose Agar (PDA)}

Potato Dectrose Agar dicampurkan dengan aquades dalam erlenmeyer, diletakkan diatas hot plate menggunakan stirrer untuk diaduk sampai larutan homogen. Erlenmeyer ditutup aluminium foil, disterilkan menggunakan autoclave pada suhu $121^{\circ} \mathrm{C}$ selama 30 menit. Larutan PDA dituang ke cawan petri, dibiarkan hingga mengeras (Muarif, 2013).

\section{Persiapan Isolat $T$. harzianum dan $T$. virens}

Isolat $T$. harzianum dan $T$. virens berasal dari tanaman pala dan tanaman kakao koleksi Laboratorium Penyakit Tanaman, Program Studi Proteksi Tanaman Fakultas Pertanian Unsyiah. Diperbanyak secara aseptik di ruang Laminar Air Flow, diinkubasi selama 5 hari pada suhu ruang $\left(25^{\circ} \mathrm{C}\right)$.

\section{Persiapan dan Perbanyakan Formulasi CairT. harzianum dan T. virens}

Isolat $T$. harzianum dan $T$. virens diperbanyak pada media cair dengan komposisi yaitu air cucian beras, air kelapa, gula pasir. Campuran bahan direbus hingga mendidih, disaring, dimasukkan ke dalam 2 buah jerigen yang sudah disterilkan dengan alkohol $70 \%$ dan ditutup rapat. Kemudian didinginkan di dalam ember berisi air. Setelah media dingin, jerigen disemprot dengan alkohol dan dimasukkan ke Laminar Air Flow. Diambil akuades, gelas ukur, jarum ose, pipet tetes dan satu cawan petri masing-masing biang $T$. harzianum dan $T$. virens yang sudah steril, diletakkan dalam Laminar Air Flow. Biang T. harzianum dan T. virens digores jarum ose dan diencerkan dengan aquades, diambil dengan pipet tetes dan dimasukkan ke dalam jerigen yang sudah diberi label : 1 (T. harzianum) dan 2 ( $T$. virens), ditutup penutup. Jerigen dikocok di multi shaker MMS sebanyak 3 kali sehari dengan kecepatan $150 \mathrm{rpm}$ selama 2 jam per pengocokan. Formulasi cair dapat digunakan 3 minggu setelah pengocokan (Soesanto, 2016).

\section{Persiapan media tanam}

Media tanam berupa tanah dari jenis entisol dari Desa Labui Kecamatan Lambaro Angan Aceh Besar yang telah dikering anginkan selama 15 hari dan diayak serta diberi campuran sekam padi dan pupuk kandang (2:1:1), dimasukkan ke polibag volume $1 \mathrm{~kg}$.

\section{Seleksi dan Penanaman Benih Kakao}

Benih kakao diperoleh dari Desa Pulo Hagu, Kecamatan Padang Tiji, Kabupaten Pidie dengan menggunakan varietas kakao lindak. Bibit kakao yang baik (sehat) memiliki kriteria yaitu : Biji kakao yang bersertifikat, biji kakao sudah masak sempurna, Biji kakao jika dimasukkan ke dalam air akan tenggelam dalam air (menguji bahwa benih bernas dan tidak kosong serta merangsang radikula keluar), berasal dari tanaman klonal, umur buah antara 150-172 dan dompolan benih sudah terlepas dari kulit buah serta dipetik dari batang utama atau cabang primer dengan ukuran buahnya sedang (Asrining, 2013). Cara secara generatif yaitu

Aplikasi Formulasi Cair Trichoderma harzianum dan Trichoderma virens sebagai Agen Pengendali Hayati (APH) Penyakit Hawar Daun (Phytopthora palmivora) pada Bibit Kakao 
buah kakao dipotong dan biji bagian tengah buah digunakan sebagai benih. Biji dibersihkan dengan menggunakan abu sekam padi sampai permukaan biji tidak berlendir, dicuci dengan air (Muarif, 2013). Benih kakao direndam dengan air selama 24 jam. Benih kakao diambil dan ditanam ke dalam polibag dengan kedalaman lubang tanam $5 \mathrm{~cm}$ dengan posisi radikula kebawah.

\section{Aplikasi Formulasi Cair Trichoderma}

Formulasi cair $T$. harzianum dan $T$. virens diaplikasikan dengan jumlah konidia atau inokulum $10^{6}$ dan $10^{3}$. Sebelum diaplikasikan formulasi cair dilakukan pengenceran. Aplikasi formulasi cair T. harzianum dan T. virens dilakukan 2 kali yaitu sebelum tanam dan sesudah tanam pada sore hari dengan cara disemprot menggunakan tudor sprayer.

\section{Inokulasi Phytopthora palmivora}

Inokulasi $P$. palmivora dilakukan 1 minggu setelah aplikasi formulasi cair $T$. harzianum dan $T$. virens. Inokulum $P$. palmivora didapat dari kulit kakao yang terinfeksi $P$. palmivora dengan kerapatan spora $1 \times 10^{6}$, disemprotkan ke permukaan daun dengan tudor sprayer dan disungkup dengan plastik selama 1 minggu (Tarigan, 2017).

\section{Pemeliharaan}

Pemeliharaan tanaman kakao meliputi penyiraman yang dilakukan 2 hari sekali yaitu pagi dan sore hari ( tergantung cuaca) dan melakukan penyiangan rumput (gulma).

\section{Peubah Yang Diamati}

\section{Masa Inkubasi Penyakit (hari)}

Masa inkubasi yaitu waktu antara permulaan inokulasi dengan timbulnya gejala yang pertama setelah inokulasi patogen. Pengamatan dilakukan setiap hari selama 7 hari setelah aplikasi patogen dengan melihat tanda-tanda serangan penyakit yaitu permukaan daun seperti terbakar yang dimulai dari tepi daun (Azis et al., 2013).

\section{Kejadian Penyakit (\%)}

\section{P. palmivora.}

Kejadian penyakit diamati pada 14 hari setelah inokulasi (HSI) patogen

\section{Intensitas penyakit (\%)}

Pengamatan intensitas penyakit dilakukan pada 28 hari setelah tanam (HST). Pengamatan dilakukan dengan mengamati setiap daun yang menunjukkan gejala dan memasukkan ke dalam skala serangan pada daun tersebut.

\section{Tinggi Tanaman (cm)}

Tinggi tanaman diukur dari pangkal batang sampai titik tumbuh daun menggunakan penggaris. Tinggi tanaman diukur pada 7, 14, 21, 28 HSI formulasi cair Trichoderma (Setyadi, 2017). 


\section{HASIL DAN PEMBAHASAN}

\section{Masa Inkubasi (Hari)}

Berdasarkan hasil uji F pada analisis ragam (Lampiran 4) menunjukkan bahwa aplikasi formulasi cair T. harzianum dan T. virens serta kombinasi keduanya berpengaruh sangat nyata terhadap masa inkubasi Phytopthora palmivora pada bibit kakao. Rata-rata masa inkubasi penyakit hawar daun pada bibit kakao akibat perlakuan formulasi cair T. harzianum dan T. virens dapat dilihat pada Gambar 1.

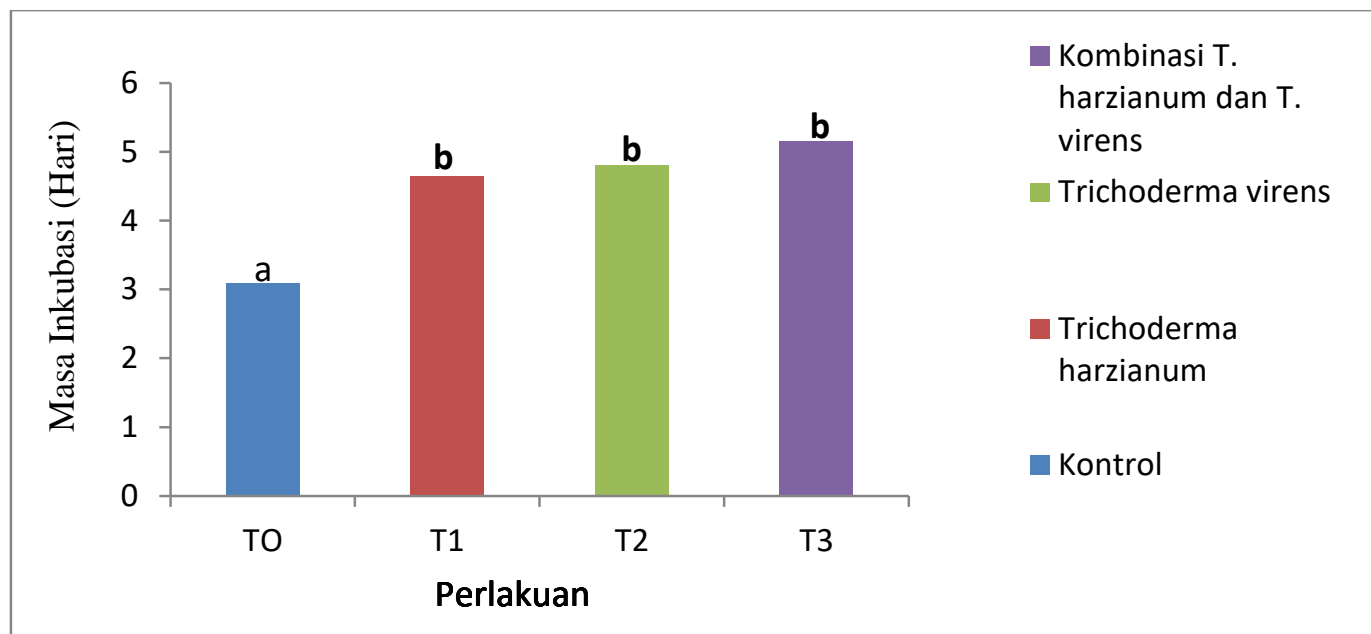

Gambar 1. Rata-rata masa inkubasi (hari) penyakit hawar daun pada daun bibit kakao. Angka-angka yang diikuti oleh huruf yang sama tidak berbeda nyata pada taraf Uji BNT 5\%.

Gambar 1 menunjukkan bahwa terdapat perbedaan yang nyata antara masa inkubasi $P$. palmivora perlakuan kontrol (T0) dengan semua masa inkubasi $P$. palmivora perlakuan lainnya, sedangkan masa inkubasi $P$. palmivora aplikasi formulasi cair T. harzianum (T1), T. virens (T2) serta kombinasi T. harzianum dan T. virens (T3) tidak berbeda nyata antar ketiganya. Masa inkubasi tercepat dijumpai pada perlakuan kontrol (T0) yaitu 3,08 hari dan terlama pada aplikasi kombinasi formulasi cair $T$. harzianum dan $T$. virens (T3) yaitu 5,16 hari. Ini menunjukkan bahwa aplikasi formulasi cair T. harzianum dan T. virens serta kombinasi keduanya mampu menekan perkembangan $P$. palmivora, dimana proses timbulnya gejala awal bergantung pada tingkat virulensi patogen sehingga terjadi perbedaan masa inkubasi. Sejalan dengan pernyataan Yudha et al. (2016), persaingan antara patogen dengan antagonis menyebabkan terjadinya penundaan masa inkubasi. Hal tersebut diduga dapat disebabkan oleh faktor lingkungan seperti suhu, $\mathrm{pH}$, kandungan air, nutrisi serta enzim (Berlian et al., 2013). T. virens mampu menghambat perkembangan $P$. palmivora dengan mekanisme antibiosisnya secara in vitro (Sriwati, 2012). Ketahanan tanaman juga mempengaruhi serta mampu memperlambat gejala penyakit hawar daun. Hal ini terlihat pada aplikasi formulasi cair T. harzianum (T1), aplikasi formulasi cair T. virens (T2) serta aplikasi kombinasi formulasi cair T. harzianum dan T. virens (T3) yang menunjukkan gejala penyakit hawar daun muncul lebih lama dibandingkan dengan perlakuan kontrol (T0). Adanya penundaan munculnya gejala penyakit hawar daun kemungkinan disebabkan tanaman telah mempunyai ketahanan secara preventif terhadap serangan cendawan patogen $P$. infestans (Purwantisari et al., 2016).

Aplikasi Formulasi Cair Trichoderma harzianum dan Trichoderma virens sebagai Agen Pengendali Hayati (APH) Penyakit Hawar Daun (Phytopthora palmivora) pada Bibit Kakao 


\subsection{Rata-rata Kejadian Penyakit (\%)}

Kejadian penyakit dihitung dengan membandingkan antara jumlah daun yang terinfeksi $P$. palmivora dengan total keseluruhan daun. Rata-rata pengamatan terhadap kejadian penyakit $P$. palmivora pada setiap perlakuan dapat dilihat pada Lampiran 5. Hasil analisis ragam (Lampiran 7) menunjukkan bahwa aplikasi formulasi cair $T$. harzianum dan $T$. virens serta kombinasi keduanya berpengaruh sangat nyata terhadap kejadian penyakit $P$. palmivora pada daun bibit kakao 14 HSI. Rata-rata kejadianpenyakit hawar daun akibat perlakuan formulasi cair $T$. harzianum dan $T$. virens terhadap hawar daun $P$. palmivora dapat dilihat pada Gambar 2.

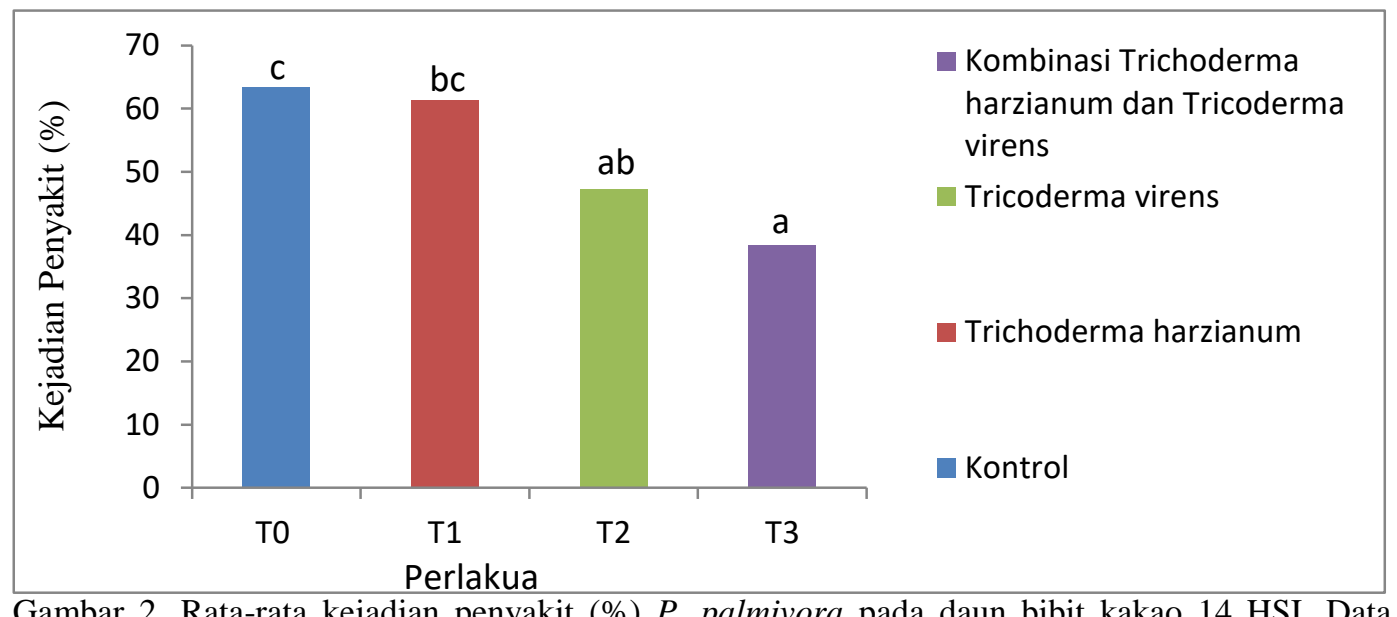

Gambar 2. Rata-rata kejadian penyakit (\%) P. palmivora pada daun bibit kakao 14 HSI. Data ditransformasi $\operatorname{Arc} \sin \sqrt{ } \mathrm{x}$.

Rata-rata persentase kejadian penyakit pada gambar 2 menunjukkan bahwa perlakuan kontrol (T0) berbeda tidak nyata dengan aplikasi formulasi cair $T$. virens (T1), namun berbeda nyata dengan aplikasi formulasi cair T.harzianum (T2) dan kombinasi keduanya (T3) terhadap kejadian penyakit. Perbedaan kejadian penyakit tersebut menunjukkan adanya kemampuan $T$. harzianum dan $T$. virens dalam menghambat perkembangan patogen penyebab penyakit hawar daun pada bibit kakao dikarenakan Trichoderma memiliki kemampuan antagonis terhadap patogen tanaman. Hifa T.harzianum dapat melilit hifa cendawan patogen tanaman sedangkan $T$. virens menghasilkan antibiotik (gliotoksin dan viridiol yang bersifat fungistatik) yang dapat menghambat pertumbuhan patogen sehingga mampu menurunkan kejadian penyakit (Hanson dan Howell, 2004; Nurhidayati, 2012). aplikasi kombinasi formulasi cair T. virens dan T.harzianum (T3) memiliki kejadian penyakit terendah dibandingkan dengan perlakuan lainnya dengan rata-rata kejadian terendah yaitu $38,30 \%$ sedangkan rata-rata persentase kejadian penyakit tertinggi terdapat pada perlakuan kontrol (T0) yaitu 63,48\%. Di lingkungan yang menguntungkan, populasi cendawan antagonis akan terus berkembang dan berpengaruh terhadap siklus hidup patogen sehingga pertumbuhan dan perkembangan tanaman semakin baik (Musfirah et al., 2018).

\section{Rata-rata Intensitas Penyakit (\%)}

Aplikasi Formulasi Cair Trichoderma harzianum dan Trichoderma virens sebagai Agen Pengendali Hayati (APH) Penyakit Hawar Daun (Phytopthora palmivora) pada Bibit Kakao 
Rata-rata intensitas penyakit hawar daun $P$. palmivora pada setiap aplikasi formulasi cair dapat dilihat pada Lampiran 8 . Hasil analisis ragam menunjukkan bahwa aplikasi formulasi cair $T$. harzianum dan $T$. virens serta kombinasi keduanya berpengaruh sangat nyata terhadap intensitas penyakit hawar daun $P$. palmivora. Rata-rata intensitas penyakit akibat aplikasi formulasi cair T.harzianum dan $T$. virens pada bibit kakao dapat dilihat pada Gambar 3.

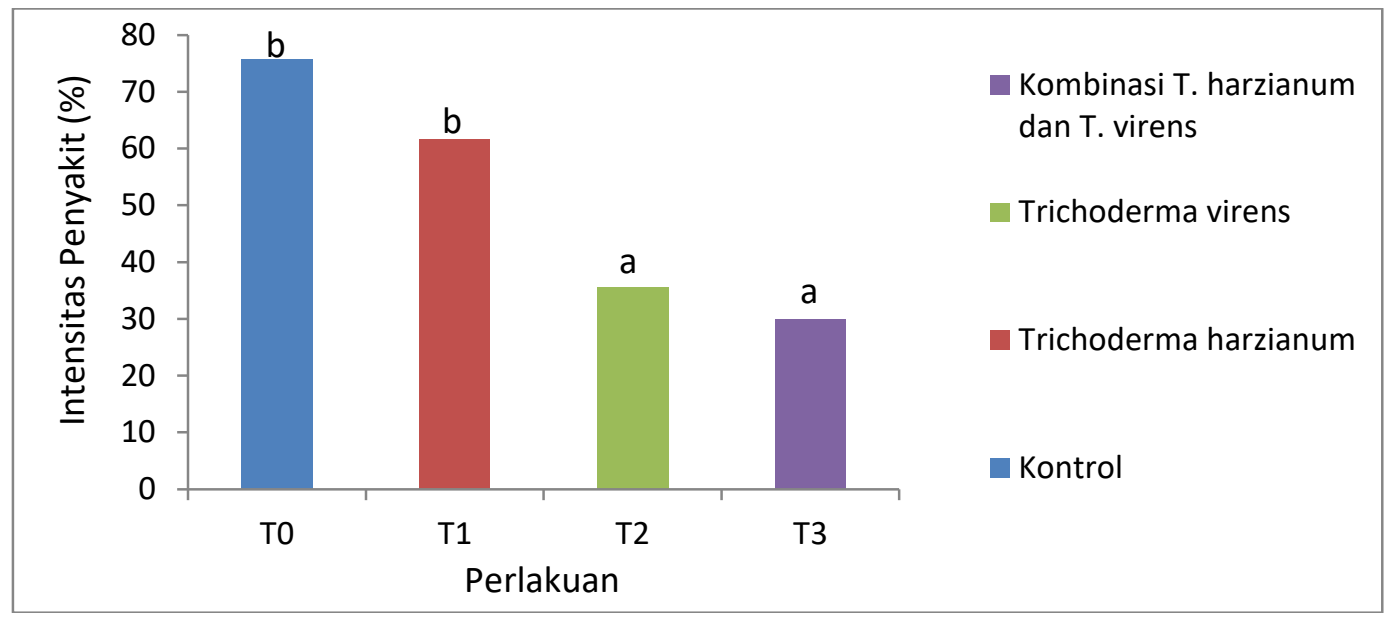

Gambar 3.Rata-rata intensitas penyakit (\%)P. palmivora pada daun bibit kakao pada 28 HSI. Angkaangka yang diikuti oleh huruf yang sama tidak berbeda nyata berdasarkan Uji BNT pada taraf 5\%. Data ditransformasi $\operatorname{Arc} \sin \sqrt{x}$.

Rata-rata persentase intensitas penyakit $P$. palmivora tertinggi terjadi pada perlakuan Kontrol (T0) yaitu 75,76\% dan tidak berbeda nyata dengan aplikasi formulasi cair T.harzianum (T1) (Gambar 3). Rata-rata persentase intensitas penyakit terendah pada aplikasi kombinasi formulasi cair $T$.harzianum dan $T$. virens (T3) dengan rata-rata persentase sebesar $29,99 \%$ yang tidak berbeda nyata dengan aplikasi formulasi cair $T$. virens (T2). Ini menunjukkan adanya pengaruh induksi ketahanan dari aplikasi formulasi cair T.harzianum dan T. virens dalam memperpanjang masa inkubasi dan menekan perkembangan $P$. palmivora. Sejalan dengan Purwantisari et al. (2016), P. infestan tidak mampu melakukan penetrasi dan melakukan perkecambahan ke dalam sel daun tanaman walaupun keadaan lingkungan sangat mendukung disebabkan oleh aplikasi T. viride. T.harzianum dan $T$. virens juga berperan sebagai penghambat perkembangan patogen dan sebagai bio-fertilizer (Vinale et al., 2014). Menurut Chamzurni et al. (2013), kombinasi $T$. harzianum dan $T$. virens efektif dalam mengendalikan Rhizoctonia solani pada pembibitan cabai.

\section{Tinggi Tanaman $(\mathrm{cm})$}

Aplikasi formulasi cair $T$. harzianum dan T. virens serta kombinasi keduanya berpengaruh sangat nyata terhadap tinggi tanaman pada bibit kakao (Lampiran 36, 38, 40 dan 42). Rata-rata tinggi tanaman bibit kakao akibat aplikasi formulasi cair T. harzianum dan T. virens dapat dilihat pada Tabel 6.

Aplikasi Formulasi Cair Trichoderma harzianum dan Trichoderma virens sebagai Agen Pengendali Hayati (APH) Penyakit Hawar Daun (Phytopthora palmivora) pada Bibit Kakao 
Tabel 6. Rata-rata Tinggi Tanaman Bibit Kakao Akibat Aplikasi Formulasi Cair T. harzianum dan T. virens $(\mathrm{cm})$

\begin{tabular}{|c|c|c|c|c|}
\hline \multirow{2}{*}{ Perlakuan } & \multicolumn{4}{|c|}{ Tinggi Tanaman Bibit Kakao (cm) } \\
\hline & 7 HSI & 14 HSI & $21 \mathrm{HSI}$ & $28 \mathrm{HSI}$ \\
\hline Kontrol ( T0 ) & $10,83 \mathrm{a}$ & $11,55 \mathrm{a}$ & $13,14 \mathrm{a}$ & $14,68 \mathrm{a}$ \\
\hline Trichoderma harzianum ( T1 ) & $14,17 \mathrm{~b}$ & $14,73 \mathrm{~b}$ & $15,34 \mathrm{~b}$ & $16,23 \mathrm{a}$ \\
\hline Trichoderma virens ( T2 ) & $13,14 \mathrm{~b}$ & $13,97 \mathrm{~b}$ & $14,53 \mathrm{~b}$ & $15,37 \mathrm{a}$ \\
\hline Kombinasi $T$. harzianum dan T. virens ( T3 ) & $15,77 \mathrm{~b}$ & $16,48 \mathrm{~b}$ & $17,68 \mathrm{c}$ & $18,75 \mathrm{~b}$ \\
\hline BNT 0,05 & 2,770 & 2,568 & 1,466 & 1,879 \\
\hline
\end{tabular}

Keterangan : angka-angka yang diikuti oleh huruf yang sama pada kolom yang sama tidak berbeda nyata berdasarkan uji BNT pada taraf $5 \%$.

Tabel 6 menunjukkan bahwa pada pengamatan 7 dan 14 HSI, perlakuan perlakuan kontrol (T0) berbeda nyata dengan perlakuan aplikasi formulasi cair lainnya. Pada pengamatan $21 \mathrm{HSI}$, aplikasi kombinasi formulasi cair T. harzianum dan $T$. virens (T3) berbeda nyata dengan perlakuan lainnya terhadap tinggi tanaman, tetapi aplikasi formulasi cair T. harzianum (T1) dan aplikasi formulasi cair (T2) tidak berbeda nyata terhadap tinggi tanaman. Pada pengamatan $28 \mathrm{HSI}$, aplikasi kombinasi formulasi cair $T$. harzianum dan $T$. virens (T3) berbeda nyata dengan perlakuan lainnya, tetapi antara perlakuan T0, T1, T2 tidak menunjukkan perbedaan yang nyata terhadap tinggi tanaman. Rata-rata tinggi tanaman bibit kakao meningkat akibat perlakuan aplikasi formulasi cair $T$. harzianum dan $T$. virens serta kombinasi keduanya. Aplikasi kombinasi formulasi cair T. harzianum dan $T$. virens (T3) memiliki rata-rata tertinggi terhadap tinggi tanaman bibit kakao pada setiap pengamatan $(7,14,21$ dan $28 \mathrm{HSI})$ dengan nilai rata-rata yaitu 15,77, $16,48,17,68$ dan $18,75 \mathrm{~cm}$ per tanaman. Perlakuan kontrol (T0) memiliki rata-rata terendah terhadap tinggi tanaman bibit kakao pada setiap pengamatan $(7,14,21$ dan 28 HSI) dengan nilai rata-rata yaitu 10,83, 11,55, 13,14 dan 14,68 cm per tanaman. Hal ini menunjukkan bahwa pemberian kedua Trichoderma tersebut mampu mendorong pertumbuhan tinggi tanaman. Haryuni (2013) juga menambahkan Trichoderma sp. merupakan jamur berfilamen yang bersifat mesofilik, tidak patogen, mempunyai kemampuan menghidrolisis selulosa dan hemiselulosa menjadi glukosa dan xylosa, dan banyak digunakan untuk memproduksi enzim selulase sehingga meningkatkan biomassa tanaman.

\section{KESIMPULAN DAN SARAN}

Aplikasi formulasi cair T. virens dan kombinasi formulasi cair T. harzianum dan T. virens mampu memperpanjang masa inkubasi Phytopthora palmivora pada bibit kakao. Aplikasi formulasi cair T. virens dan kombinasi formulasi cair $T$. harzianum danT. virens mampu menurunkan kejadian penyakit dan intensitas penyakit pada bibit kakao. Aplikasi kombinasi formulasi cair T. harzianum dan $T$.

Aplikasi Formulasi Cair Trichoderma harzianum dan Trichoderma virens sebagai Agen Pengendali Hayati (APH) Penyakit Hawar Daun (Phytopthora palmivora) pada Bibit Kakao 
virens serta kombinasi keduanya, mampu meningkatkan pertumbuhan dan perkembangan bibit kakao pada peubah tinggi tanaman yaitu $18,75 \mathrm{~cm}$ per tanaman.

Perlu dilakukan penelitian lanjutan di lapangan untuk mengetahui pengaruh dari formulasi cair $T$. harzianum dan $T$. virens serta kombinasi keduanya yang mampu dalam menghambat $P$. palmivora pada kakao.

\section{DAFTAR PUSTAKA}

Afriyeni, Y., N. Nasir, Periadnadi dan Jumjunidang. 2013. Jenis-jenis jamur pada pembusukan buah kakao (Theobroma cacao L.) di Sumatera Barat. Biologi. Universitas Andalas, Padang. 2(2):124-129.

Asrining, W.C. 2013. Pembuatan bahan tanam unggul kakao hibrida F1. Balai Besar Perbenihan dan Proteksi tanaman Perkebunan Surabaya. Surabaya.

Azis, A.I., A. Rosmana dan V.S. Dewi. 2013. Pengendalian penyakit hawar daun Phytopthora pada bibit kakao dengan Trichoderma asperellum. Jurnal Fitopatologi. 9:15-20 (1).

Badan Pusat Statistik Provinsi Aceh. 2013. https://aceh.bps.go.id/dynamic table/2016/04/27/luas-tanam-dan-produksi-kakao-perkebunan-rakyatmenurut-kabupaten-kota-2013-2013.html. Diakses tanggal 27-09-2018

Berlian, I., B. Setyawan dan H. Hadi. 2013. Mekanisme antagonisme Trichoderma spp. terhadap beberapa patogen tular tanah. Warta Perkaretan. 32(2): 74-82.

Chamzurni, T., H. Oktarina dan K. Hanum. 2013. Keefektifan Trichoderma harzianum dan Trichoderma virens untuk mengendalikan Rhizoctania solani Kuhn pada bibit cabai (Capsicum annum L). Jurnal Agrista. 17(1): 21-17.

Dinas Perkebunan dan Hortikultura (2016). Rencana kebutuhan teknologi dinas perkebunan dan hortikultura tahun 2016. Dinas Perkebunan dan Hotikultura. Propinsi Sulawesi Tenggara, 11 p.

Hanson, L.E. dan C.R. Howell. 2004. Elicitors of plant defense response elisator respon biocontrol strains of Trichoderma virens. Phytopathology. 94(2): 171176.

Haryuni. 2013. Perbaikan pertumbuhan dan hasil stevia (Stevia rebaudiana BERTONIM) melalui aplikasi Trichoderma sp. Jurnal Biosaintifika. 5(2):5863.

Howell, C.R. 2003. Mechanisms Employed by Trichoderma species in the Biological Control of Plant Disease: The History and Evaluation of Current Concepts. PlantDisease, 87 (1) : $4-10$.

Muarif, R. 2013. Uji konsentrasi Trichoderma virens dalam menghambat perkembangan Phytopthora palmivora pada bibit kakao. Skripsi. Program Studi Agroteknologi Fakultas Pertanian Universitas Syiah Kuala. Banda Aceh.

Aplikasi Formulasi Cair Trichoderma harzianum dan Trichoderma virens sebagai Agen Pengendali Hayati (APH) Penyakit Hawar Daun (Phytopthora palmivora) pada Bibit Kakao 
Musfirah, R., R. Sriwati dan T. Chamzurni. 2018. Uji masa simpan pelet Trichoderma harzianum dan kemampuannya dalam menghambat perkembangan penyakit layu Fusarium pada bibit tomat. JIM Pertanian Unsyiah. 3(2): 2018.

Nurhidayati, A. Umayah dan S.E. Agustin. 2012. Aplikasi Trichoderma spp. melalui penyemprotan pada daun, akar dan perendaman akar untuk menekan infeksi penyakit downy mildew pada tanaman caisin. J. Dharmapala. 4:2228.

Purwantisari, S., A. Priyatmojo, R.P. Sancayaningsih dan R.S. Kasiamdari. 2016. Masa inkubasi gejala penyakit hawar daun tanaman kentang yang diinduksi ketahanannya oleh jamur antagonis Trichoderma viride. Jurnal Bioma. 18(1):41-47.

Setyadi, I.M.D., I.N. Artha dan G.N.A.S. Wirya. 2017. Efektifitas pemberian kompos Trichoderma sp. terhadap pertumbuhan tanaman cabai (Capsicum annum L.). Jurnal Agroteknologi Tropika. 6(1):21-30.

Soesanto, L. 2014. Metabolit sekunder agensia pengendali hayati: terobosan baru pengendalian organisme pengganngu tanaman perkebunan. Fakultas Pertanian, Universitas Jenderal Soedirman. Purwokerto.

Soesanto, L. 2016. Teknologi Praktis Perbanyakan Agensia Pengendali Hayati. Fakultas Pertanian, Universitas Jenderal Soedirman. Purwokerto.

Sriwati, R. 2012. The use of Trichoderma for management of cacao diseases by field apllication and development of organic compost. Fellowship Report. WCF-Aceh Cocoa Fellowship.

Suwahyono, U. 2013 Membuat Biopestisida. Penebar Swadaya. Jakarta.

Tarigan, Y. S. 2017. Aplikasi pelet Trichoderma spp. dalam bentuk suspensi sebagai agen pengendalian hayati (APH) penyakit hawar daun (Phytophtora palmivora) pada bibit kakao. Skripsi. Fakultas Pertanian. Universitas Syiah Kuala. Banda Aceh.

Umrah, U., T. Anggraini., R. R. Esyanti dan I. N. P. Aryantha. 2009. Antagonisitas dan efektivitas Trichoderma spp dalam menekan perkembangan Phytophthora palmivora pada buah kakao. Agroland. 16(1) : 9-16.

Vinale, F., K. Sivasithamparam, E. L. Ghisalberti, S. Woo, L. Nigro, M. Marra, R.,........ Lorito. 2014. Trichoderma secondary metabolites active on plants and fungal pathogens. The Open Mycology Journal. 8(1): 127-139.

Yudha, M.K., L. Soesanto dan E. Mugiastuti. 2016. Pemanfaatan empat isolat Trichoderma sp. untuk mengendalikan penyakit akar gada pada tanaman caisin. Jurnal Kultivasi. 15(3):143-149.

Aplikasi Formulasi Cair Trichoderma harzianum dan Trichoderma virens sebagai Agen Pengendali Hayati (APH) Penyakit Hawar Daun (Phytopthora palmivora) pada Bibit Kakao 